Marquette University

e-Publications@Marquette

School of Dentistry Faculty Research and

Publications

Dentistry, School of

$5-1-2016$

Acrylic Resin Guide for Locating the Abutment Screw Access Channel of Cement-Retained Implant Prostheses

\author{
Ayman Ahmed \\ Marquette University, ayman.ahmed@marquette.edu \\ Georgios Maroulakos \\ Marquette University, georgios.maroulakos@marquette.edu \\ Jorge Garaicoa \\ Oregon Health Sciences University
}

Accepted version. The Journal of Prosthetic Dentistry, Vol. 115, No. 5 (May 2016): 560-563. DOI. (C) 2015 Editorial Council for The Journal of Prosthetic Dentistry. Used with permission. 


\title{
Acrylic Resin Guide for Locating the Abutment Screw Access Channel of Cement-Retained Implant Prostheses
}

\author{
Ayman Ahmed \\ Department of General Dental Sciences, Marquette University \\ School of Dentistry, \\ Milwaukee, WI \\ Georgios Maroulakos \\ Department of General Dental Sciences, Marquette University \\ School of Dentistry, \\ Milwaukee, WI \\ Jorge Garaicoa \\ Department of Restorative Dentistry, Oregon Health Sciences \\ University School of Dentistry, \\ Portland, OR
}

\begin{abstract}
Abutment screw loosening represents a common and challenging technical complication of cement-retained implant prostheses. This article describes the fabrication of a simple and accurate poly(methyl methacrylate)

The Journal of Prosthetic Dentistry, Vol 115, No. 5 (May 2016): pg. 560-563. DOI. This article is @ Elsevier and permission has been granted for this version to appear in e-Publications@Marquette. Elsevier does not grant permission for this article to be further copied/distributed or hosted elsewhere without the express permission from Elsevier.
\end{abstract}


NOT THE PUBLISHED VERSION; this is the author's final, peer-reviewed manuscript. The published version may be accessed by following the link in the citation at the bottom of the page.

guide for identifying the location and angulation of the abutment screw access channel of a cement-retained implant prosthesis with a loosened abutment screw.

Cement-retained implant prostheses have certain advantages over screw-retained implant prostheses, such as reduced fabrication complexity and costs, better passivity of fit, development of proper occlusal contacts, and superior esthetics. ${ }^{1}$ However, one major disadvantage is prosthesis retrievability. This is particularly important when a biomechanical implant failure occurs, such as abutment screw loosening. Screw loosening is a common technical complication, 2, 3, 4 and 5 with a reported annual incidence rate of $2.1 \%,{ }^{6}$ and a 5 -year cumulative incidence rate of $8.8 \% .^{3}$ Based on implant connection design, screw loosening has a reported 3-year cumulative incidence of $1.5 \%$ for internal connection and $7.5 \%$ for external connection designs. ${ }^{4}$

When screw loosening occurs, the implant prosthesis must be removed. This is achieved by sectioning the prosthesis, which will require complete replacement and possibly cause structural damage to the abutment or the implant. The use of interim cements has been recommended, ${ }^{7}$ but this may not result in predictable retrieval of the prosthesis. Retrieval systems using small removable lingual screws $^{8}$ and 9 or rotating levers ${ }^{9}$ have been described but are not popular because of increased fabrication complexity. Other methods that have been used to successfully locate the screw access channel are extraoral and intraoral photography, 10,11,12,13 and 14 intraoral radiography, ${ }^{15}$ and 16 occlusal ceramic stain to mark the screw access

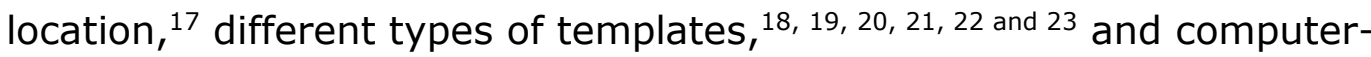
aided design/computer-aided manufacture (CAD/CAM) technology. 20 and 24 Most of these techniques do not provide 3dimensional information, as they show only the location and not the angulation of the screw access channel. $10,11,12,13,15,16,17,18,19$ and 21 Some techniques require access to specialized equipment or may be impractically expensive. ${ }^{20}$ and 24 Other techniques describe the fabrication of a template from a combination of different materials, which may result in a template with compromised fit or integrity that cannot be used predictably. 22 and 23

The Journal of Prosthetic Dentistry, Vol 115, No. 5 (May 2016): pg. 560-563. DOI. This article is @ Elsevier and permission has been granted for this version to appear in e-Publications@Marquette. Elsevier does not grant permission for this article to be further copied/distributed or hosted elsewhere without the express permission from Elsevier. 
The purpose of this article was to describe a technique for the fabrication of a poly (methyl methacrylate) (PMMA) guide to identify the abutment screw access channel in a cement-retained implant crown with a loosened abutment screw. This technique uses a thin drill that can fit into the implant analog connection and subsequently transfer the screw channel location and angulation to the acrylic resin guide. It is simple and inexpensive and results in an accurate, precise, and durable guide. This technique could also be used with multiple unit implant partial fixed dental prostheses. A disadvantage of the described technique is that it can be used more successfully with implants that have an internal connection design. Also, the original implant analog cast must be preserved. However, this problem may be overcome if the screw access guide is fabricated before the cementation of the implant prosthesis and retained for future use.

\section{Technique}

1. Locate the implant prosthesis with the loosened abutment screw (Fig. 1) and make an irreversible hydrocolloid impression (Jeltrate; Dentsply Intl) of the pertinent arch. Pour the impression in type 3 dental stone (Microstone; Whip Mix Corp). Trim the cast, leaving 1 to 3 teeth on each side of the loosened implant prosthesis.



Figure 1. Cement-retained gold implant crown on maxillary right first molar with loosened abutment screw.

2. Survey the trimmed cast and mark the height of contour.

The Journal of Prosthetic Dentistry, Vol 115, No. 5 (May 2016): pg. 560-563. DOI. This article is (C) Elsevier and permission has been granted for this version to appear in e-Publications@Marquette. Elsevier does not grant permission for this article to be further copied/distributed or hosted elsewhere without the express permission from Elsevier. 
NOT THE PUBLISHED VERSION; this is the author's final, peer-reviewed manuscript. The published version may be accessed by following the link in the citation at the bottom of the page.

3. Mold silicone laboratory putty (GCLT Laboratory Putty; GC America) over the cast and cut the excess material at the height of contour leaving the material below the height of contour on the cast (Fig. 2).

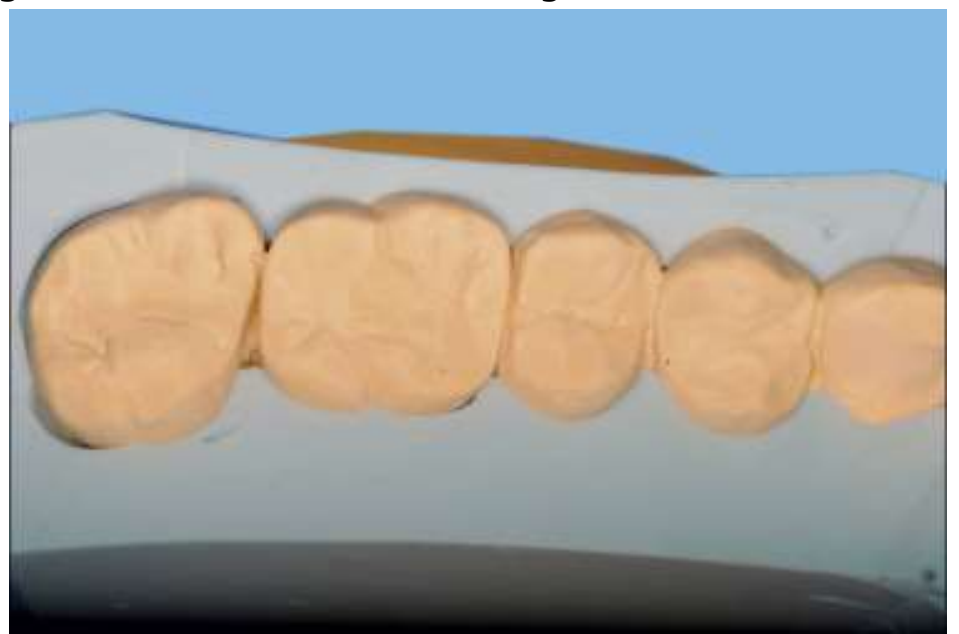

Figure 2. Silicone laboratory putty blocking tooth surfaces apical to their height of contour on cast.

4. Box the cast (Modern Materials Boxing Wax; Heraeus Kulzer North America) and apply petroleum jelly (Vaseline; Unilever) (Fig. 3).

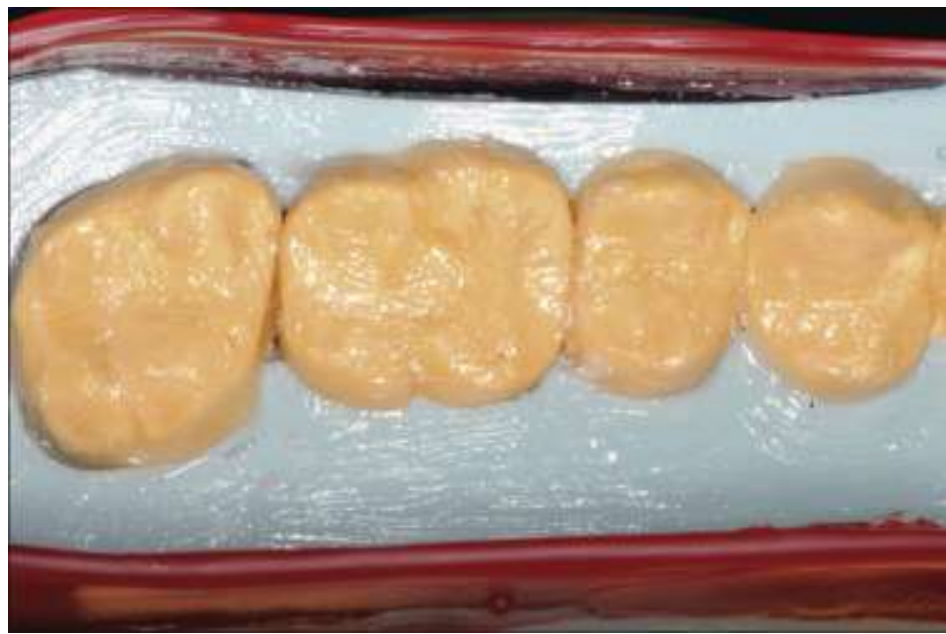

Figure 3. Cast and silicone putty block-out boxed with wax and lubricated with petroleum jelly.

5. Mix clear autopolymerizing PMMA material (Splint Resin; Great Lakes Orthodontics) and pour it on the boxed cast (Fig. 4). Place in a pressure pot at $0.14 \mathrm{MPa}$ for 15 minutes. 


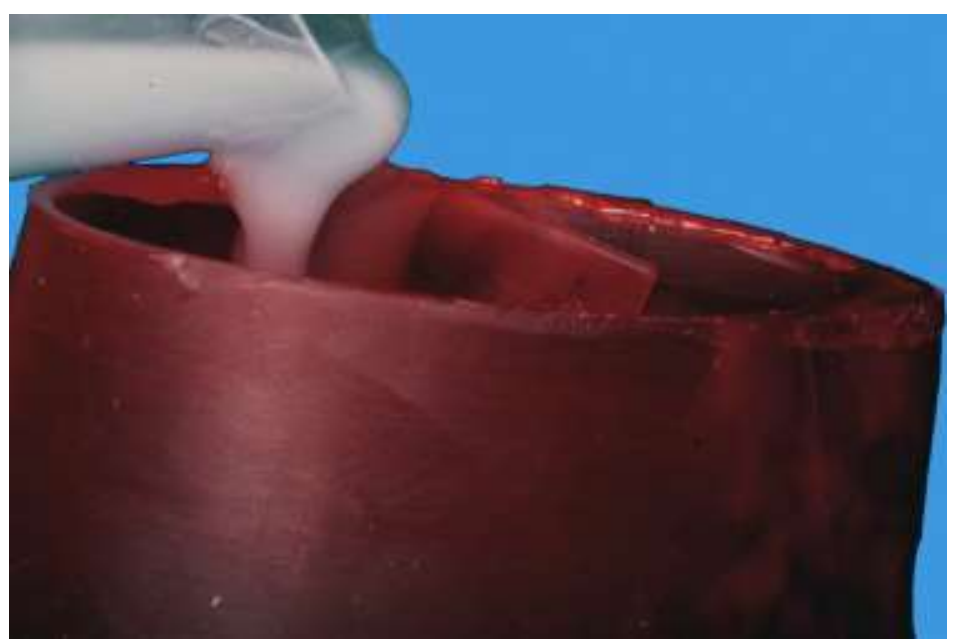

Figure 4. Mixed autopolymerizing poly(methyl methacrylate) poured into boxed cast.

6. Trim and polish the polymerized guide leaving approximately 3 to 5 $\mathrm{mm}$ of material thickness above the occlusal surfaces.

7. Place the PMMA guide over the original analog cast from which the implant prosthesis was fabricated and ensure it is stable.

8. Place the cast on the surveyor table on a drill press. Mount a 2-mmdiameter drill on the drill press. Adjust the table so that the drill is aligned to and fits into the connection channel of the implant analog and tighten the surveyor table screw. Use a narrower drill if necessary (Fig. 5).

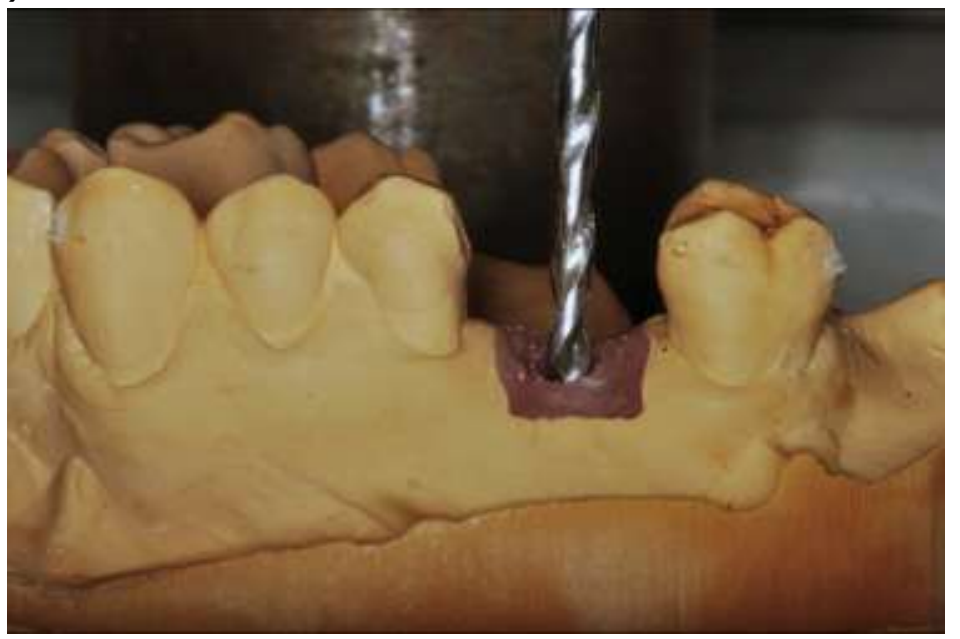

Figure 5. Original implant analog cast on surveyor table on drill press. Drill aligned to long axis of implant analog.

9. Place the PMMA guide on the cast and drill through the guide (Fig. 6). 
NOT THE PUBLISHED VERSION; this is the author's final, peer-reviewed manuscript. The published version may be accessed by following the link in the citation at the bottom of the page.

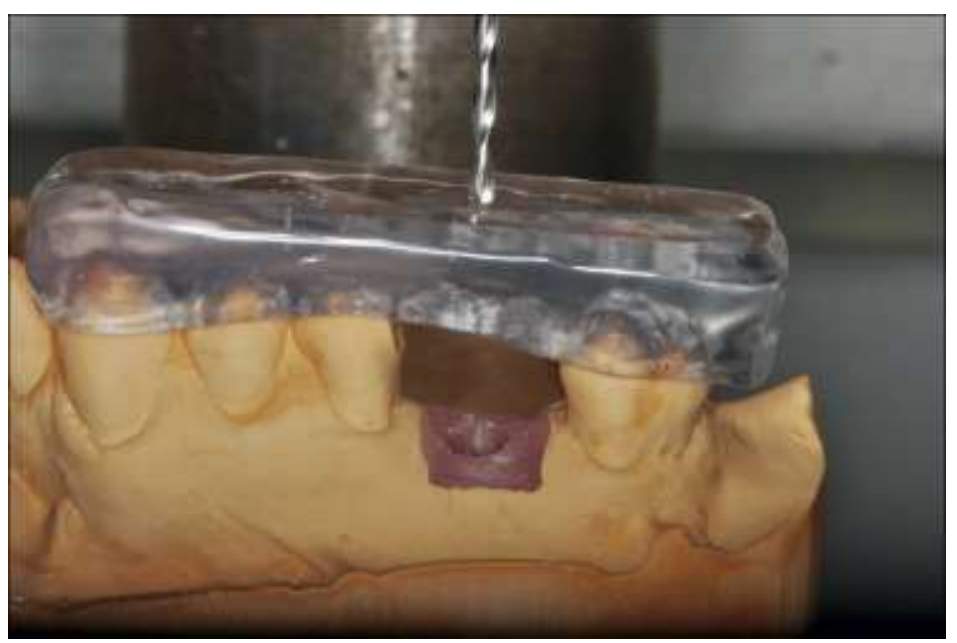

Figure 6. Poly(methyl methacrylate) guide positioned over original cast on drill press. Drill has been driven through guide.

10. Place the PMMA guide intraorally. Drill through the crown with a \#6 round tungsten carbide bur (000093U4; Brasseler USA) until the screw access channel is reached (Fig. 7). Remove the crown and custom abutment assembly.

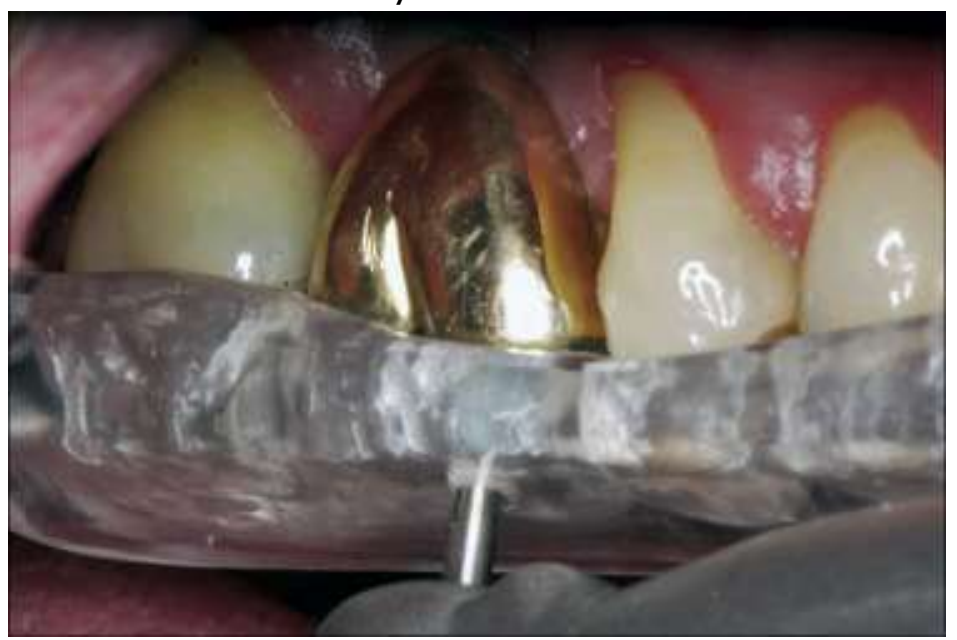

Figure 7. Cement-retained prosthesis accessed with poly(methyl methacrylate) guide and round tungsten carbide bur.

11. Reposition the crown intraorally and replace and tighten the abutment screw to the recommended torque. Cover the cervical portion of the screw access channel with polytetrafluoroethylene (Teflon; DuPont) tape. Restore the coronal $3 \mathrm{~mm}$ of the screw access channel with an appropriate restorative material. Evaluate the occlusion and polish (Fig. 8).

The Journal of Prosthetic Dentistry, Vol 115, No. 5 (May 2016): pg. 560-563. DOI. This article is (C Elsevier and permission has been granted for this version to appear in e-Publications@Marquette. Elsevier does not grant permission for this article to be further copied/distributed or hosted elsewhere without the express permission from Elsevier. 
NOT THE PUBLISHED VERSION; this is the author's final, peer-reviewed manuscript. The published version may be accessed by following the link in the citation at the bottom of the page.

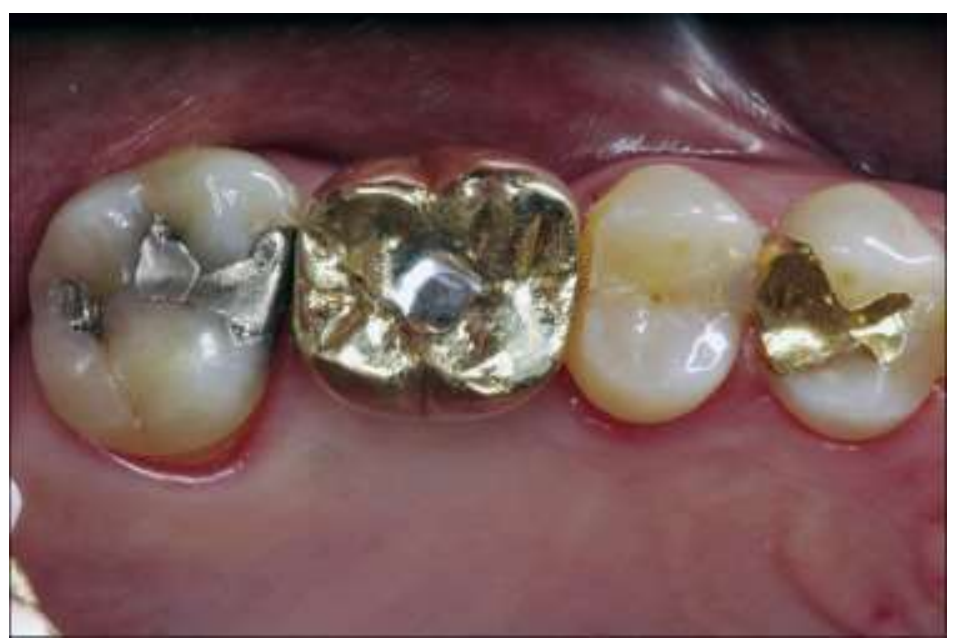

Figure 8. Coronal aspect of screw access channel was restored with amalgam after abutment screw was replaced and tightened.

\section{Discussion and Summary}

Abutment screw loosening is a common technical complication of implant prostheses. This article describes a straightforward and inexpensive method of fabricating a clear PMMA guide that transfers the implant long axis location in order to access the abutment screw channel accurately and precisely. The cement-retained prosthesis and abutment could be removed in one piece without damage.

Alternatively, this guide could be fabricated before inserting the implant prosthesis in case a technical complication occurs.

\section{References}

${ }^{1}$ K.X. Michalakis, H. Hirayama, P.D. Garefis. Cement-retained versus screwretained implant restorations: a critical review. Int J Oral Maxillofac Implants, 18 (2003), pp. 719-728

2 C.J. Goodacre, G. Bernal, K. Rungcharassaeng, J.Y. Kan. Clinical complications with implants and implant prostheses. J Prosthet Dent, 90 (2003), pp. 121-132

${ }^{3}$ R.E. Jung, A. Zembic, B.E. Pjetursson, M. Zwahlen, D.S. Thoma. Systematic review of the survival rate and the incidence of biological, technical, and aesthetic complications of single crowns on implants reported in longitudinal studies with a mean follow-up of 5 years. Clin Oral Implants Res, 23 (suppl 6) (2012), pp. 2-21 
NOT THE PUBLISHED VERSION; this is the author's final, peer-reviewed manuscript. The published version may be accessed by following the link in the citation at the bottom of the page.

${ }^{4}$ S. Gracis, K. Michalakis, P. Vigolo, P. Vult von Steyern, M. Zwahlen, I. Sailer. Internal vs. external connections for abutments/reconstructions: a systematic review. Clin Oral Implants Res, 23 (suppl 6) (2012), pp. 202-216

5 S. Ma, A. Fenton. Screw- versus cement-retained implant prostheses: a systematic review of prosthodontic maintenance and complications. Int J Prosthodont, 28 (2015), pp. 127-145

${ }^{6}$ P. Papaspyridakos, C.J. Chen, S.K. Chuang, H.P. Weber, G.O. Gallucci. A systematic review of biologic and technical complications with fixed implant rehabilitations for edentulous patients. Int J Oral Maxillofac Implants, 27 (2012), pp. 102-110

7 K. Michalakis, A.L. Pissiotis, K. Kang, H. Hirayama, P.D. Garefis, H. Petridis. The effect of thermal cycling and air abrasion on cement failure loads of 4 provisional luting agents used for the cementation of implantsupported fixed partial dentures. Int J Oral Maxillofac Implants, 22 (2007), pp. 569-574

${ }^{8}$ F.P. Valbao Jr., E.G. Perez, M. Breda. Alternative method for retention and removal of cement-retained implant prostheses. J Prosthet Dent, 86 (2001), pp. 181-183

9 T. Ichikawa, O. Ishida, M. Watanabe, Y. Tomotake, H. Wei, C. Jianrong. A new retrieval system for cement-retained implant superstructures: a technical report. J Prosthodont, 17 (2008), pp. 487-489

10 T. Daher, S.M. Morgano. The use of digital photographs to locate implant abutment screws for implant-supported cement-retained restorations. J Prosthet Dent, 100 (2008), pp. 238-239

11 O. Figueras-Alvarez, R. Cedeno, J. Cano-Batalla, J. Cabratosa-Termes. A method for registering the abutment screw position of cementretained implant restorations. J Prosthet Dent, 104 (2010), pp. 60-62

12 P.G. Patil, S.P. Patil. Occlusal-view photograph of a cement-retained implant prosthesis as a permanent guide for access-hole preparation. J Prosthet Dent, 109 (2013), pp. 343-344

13 O. Figueras-Alvarez, J. Cano-Batalla. An alternative method for registering the abutment screw position of cement-retained implant restorations. J Prosthet Dent, 112 (2014), pp. 1304-1305

$14 \mathrm{~J} . \mathrm{H}$. Lee. A technique for recording the abutment screw angulation of cement-retained implant prostheses. J Prosthet Dent, 114 (2015), pp. 741-742

15 P.G. Patil. A technique for repairing a loosening abutment screw for a cement-retained implant prosthesis. J Prosthodont, 20 (2011), pp. 652-655

16 M.M. Buzayan, W.A. Mahmood, N.B. Yunus. A simple procedure for retrieval of a cement-retained implant-supported crown: a case report. Quintessence Int, 45 (2014), pp. 125-128

The Journal of Prosthetic Dentistry, Vol 115, No. 5 (May 2016): pg. 560-563. DOI. This article is @ Elsevier and permission has been granted for this version to appear in e-Publications@Marquette. Elsevier does not grant permission for this article to be further copied/distributed or hosted elsewhere without the express permission from Elsevier. 
NOT THE PUBLISHED VERSION; this is the author's final, peer-reviewed manuscript. The published version may be accessed by following the link in the citation at the bottom of the page.

${ }^{17}$ E.R. Schwedhelm, A.J. Raigrodski. A technique for locating implant abutment screws of posterior cement-retained metal-ceramic restorations with ceramic occlusal surfaces. J Prosthet Dent, 95 (2006), pp. 165-167

$18 \mathrm{~J}$. Doerr. Simplified technique for retrieving cemented implant restorations. J Prosthet Dent, 88 (2002), pp. 352-353

19 E.E. Hill. A simple, permanent index for abutment screw access for cemented implant-supported crowns. J Prosthet Dent, 97 (2007), pp. 313-314

${ }^{20} \mathrm{H}$. W. Kang, D.H. Lee. Using a guide template with a handpiece sleeve to locate the abutment screw position of a cement-retained implant restoration. J Prosthet Dent, 114 (2015), pp. 339-342

21 J.L. Tarlow. A modified technique to locate the abutment screw access opening of a cemented implant-supported restoration. J Prosthet Dent, 108 (2012), pp. 58-59

${ }^{22}$ C. Wadhwani, K.H. Chung. Simple device for locating the abutment screw position of a cement-retained implant restoration. J Prosthet Dent, 109 (2013), pp. 272-274

23 J. Lautensack, V. Weber, S. Wolfart. Template to determine the position and angulation of the abutment screw channel for implant-supported, cement-retained restorations. J Prosthet Dent, 107 (2012), pp. 134136

24 J.I. Park, T.H. Yoon. A three-dimensional image-superimposition CAD/CAM technique to record the position and angulation of the implant abutment screw access channel. J Prosthet Dent, 109 (2013), pp. 5760

Corresponding author: Dr. Georgios Maroulakos, 415 E. Vine St, \#304, Milwaukee, WI 53212

The Journal of Prosthetic Dentistry, Vol 115, No. 5 (May 2016): pg. 560-563. DOI. This article is (C) Elsevier and permission has been granted for this version to appear in e-Publications@Marquette. Elsevier does not grant permission for this article to be further copied/distributed or hosted elsewhere without the express permission from Elsevier. 